\title{
GENDER CHARACTERISTICS OF DEPRESSIVE SYMPTOMS OF DEMENTIA IN PATIENTS WITH SUICIDAL BEHAVIOR
}

\author{
Mudrenko I.
}

\author{
Sumy State University Medical Institute, Ukraine
}

\begin{abstract}
Dementia is in most cases comorbid, which greatly reduces the quality of patients' life and increases the risk of suicidal manifestations.

The aim of the study is to determine gender characteristics of depressive symptoms in patients with various clinical types of dementia with high suicide risk.

The object and methods of research. The study involved examination of 105 patients with dementia of different types (due to Alzheimer's disease, vascular and mixed one) with high suicide risk using the Hamilton Deppression Rating Scale (HDRS).

Results of the research. Statistical analysis showed that a high degree of depression is a marker of suicidal risk in men with a vascular type of dementia, and in women with a mixed type of dementia. Verbalization (statement of suicidal intentions, thoughts) and the behavioral component of suicidal behavior (attempts) with a pronounced torpidity of mental processes are typical for men with Alzheimer's disease and vascular dementia and for women with a mixed type of dementia.

In women, affective oscillations during the day increased SR in Alzheimer's disease, and frequent wakening at night in mixed dementia. Physical limitations and inability to perform work, the problems with sexual vigor can be considered a psychogenic factor of high SR in men with vascular impairment.

Key words: dementia in Alzheimer's disease, vascular dementia, mixed dementia, gender differences, depressive symptoms, predictors of suicidal behavior.
\end{abstract}

Introduction. In recent works we proved that the presence and intensity of depressive symptoms, depressive episodes in past and suicidal attempts in history and/or in the family belong to the main clinical-psychopathological predictors of suicidal behavior (SB) in dementia $[1,2]$. We marked correlation dependence of high suicidal risk (SR) with different types of depression: inhibited, agitated, phobic and somatic. In the structure of depression in patients with SB, such symptoms as depressed mood, sleep disturbance, retardation of mental processes, feeling of helplessness and exhaustion, stress and anxiety, feeling of guilt, disorientation and disorganization of the psyche [3-5] prevail. We decided to consider the gender differences of the depressive component of dementia as the main predictor of SB in this pathology.

\section{Corresponding Author:}

Irina Mudrenko, MD, PhD, Professor assistant, Department of Neurosurgery and Neurology, Sumy State University Medical Institute, Ukraine. E-mail:mudrenko.irina@gmail.com
2. Purposes, subjects and methods:

2.1. Purpose - of our study is to consider the gender peculiarities of depressive symptoms in patients with high SR in different types of dementia and the formation of differentiated predictors of SB in men and women with this disorder.

2.2. Subjects \& Methods. We analyzed gender differences in clinical and psychopathological status of patients with high risk of suicide in different clinical types of dementia (as a result of Alzheimer's disease, vascular and mixed types of the dementia process). Only the patients of the main group with high suicidal risk according to the "Method of determining suicidal risk" $>23$ points and clinical manifestations of SB (with the presence of suicidal thoughts, decisions, intentions, attempts, etc.) took part in the research. Thus, a group of patients with dementia due to Alzheimer's disease consisted of 36 patients (15 men, 21 women), a group of patients with vascular dementia - 39 patients (25 men, 14 women), 30 patients with mixed dementia (15 men, 15 women). The examination of patients was carried out at O. V. Spivak Sumy 
Table 1

Gender characteristics of depressive symptoms in patients with Alzheimer's disease (according to the Hamilton scale)

\begin{tabular}{|c|c|c|c|c|c|c|}
\hline \multirow[t]{2}{*}{ Indicator } & Men & Women & t-value & $\mathrm{P}$ & $\begin{array}{l}\text { DC (diagno- } \\
\text { stic } \\
\text { coefficient) }\end{array}$ & $\begin{array}{c}\text { MI } \\
\text { (measure } \\
\text { of informa- } \\
\text { tiveness) }\end{array}$ \\
\hline & \multicolumn{6}{|c|}{$\mathrm{M} \pm \mathrm{SD}$} \\
\hline 1 & 2 & 3 & 4 & 5 & 6 & 7 \\
\hline Depressive mood & $1.71 \pm 0.27$ & $1.79 \pm 0.35$ & 0.161 & - & -0.065 & 0.005 \\
\hline Feeling of guilt & $1.3 \pm 0.37$ & $1.4 \pm 0.14$ & 0.239 & - & -0.104 & 0.010 \\
\hline Suicidal intentions & $3.04 \pm 0.34$ & 2 & 3.068 & $\mathrm{p}<0.01$ & 0.607 & 0.636 \\
\hline Early insomnia & $1.42 \pm 0.17$ & $1 \pm 0.18$ & 1.690 & - & 0.515 & 0.220 \\
\hline Middle insomnia & $1.42 \pm 0.17$ & $1 \pm 0.18$ & 1.690 & - & 0.515 & 0.220 \\
\hline Late insomnia & $1.23 \pm 0.16$ & $0.17 \pm 0.22$ & 1.89 & - & 2.830 & 3.012 \\
\hline Work and activity & $3.61 \pm 0.17$ & $3.78 \pm 0.11$ & 0.79 & - & -0.065 & 0.010 \\
\hline Inhibition & $2.57 \pm 0.22$ & $1.78 \pm 0.28$ & 2.18 & $\mathrm{p}<0.05$ & 0.525 & 0.412 \\
\hline Excitement & $2.23 \pm 0.32$ & $2.35 \pm 0.42$ & 0.222 & - & -0.074 & 0.008 \\
\hline Mental anxiety & $2.04 \pm 0.31$ & $1.71 \pm 0.36$ & 0.688 & - & 0.256 & 0.085 \\
\hline Somatic anxiety & $1.23 \pm 0.21$ & $1.78 \pm 0.35$ & 1.328 & - & -0.528 & 0.289 \\
\hline Main somatic violations & $0.80 \pm 0.16$ & $1.28 \pm 0.22$ & 1.733 & - & -0.667 & 0.311 \\
\hline $\begin{array}{l}\text { General somatic } \\
\text { symptoms }\end{array}$ & $1.19 \pm 0.08$ & $1.5 \pm 0.13$ & 1.885 & - & -0.333 & 0.103 \\
\hline Genital symptoms & $0.85 \pm 0.22$ & $1 \pm 0.27$ & 0.409 & - & -0.222 & 0.031 \\
\hline Hypochondria & $0.90 \pm 0.27$ & $1.071 \pm 0.3$ & 0.371 & - & -0.243 & 0.040 \\
\hline Weight loss & $0.57 \pm 0.17$ & $1 \pm 0.27$ & 1.302 & - & 1.069 & 0.319 \\
\hline Weight loss (actual) & $0.19 \pm 0.08$ & $0.42 \pm 0.22$ & 0.975 & - & -1.169 & 0.278 \\
\hline Criticism & $1.19 \pm 0.16$ & $0.71 \pm 0.12$ & 2.311 & $\mathrm{p}<0.05$ & 0.737 & 0.351 \\
\hline Daily fluctuations & $0.19 \pm 0.08$ & $1.57 \pm 0.22$ & 5.66 & $\mathrm{p}<0.001$ & -3.044 & 4.204 \\
\hline $\begin{array}{l}\text { Daily fluctuations } \\
\text { (degree) }\end{array}$ & $0.19 \pm 0.08$ & $1.28 \pm 0.22$ & 4.612 & $\mathrm{p}<0.001$ & -2.75 & 3.017 \\
\hline $\begin{array}{l}\text { Depersonalization/ } \\
\text { de-realisation }\end{array}$ & $1.71 \pm 0.35$ & $0.85 \pm 0.27$ & 1.894 & - & 1.0 & 0.857 \\
\hline Paranoid symptoms & $0.57 \pm 0.11$ & $1.28 \pm 0.22$ & 3.637 & $\mathrm{p}<0.01$ & -1.910 & 3.013 \\
\hline $\begin{array}{l}\text { Obsessive and } \\
\text { compulsive symptoms }\end{array}$ & $0.57 \pm 0.17$ & $0 \pm 0$ & 3.230 & $\mathrm{p}<0.01$ & 0 & 0 \\
\hline Total score & $32.2 \pm 1.22$ & $31 \pm 2.71$ & 0.407 & - & -3.128 & 17.448 \\
\hline
\end{tabular}

Regional Clinical Psychoneurological Health Center, Sumy Regional Clinical Hospital for War Veterans, Geriatric Boarding House, Sumy City Hospital No.4. All patients or their relatives agreed to participate in the study. The diagnosis was established in accordance with ICD-10, based on data from a clinical and neuroimaging study (MRI).

Our aim was to develop pathognomonic clinical and psychopathological diagnostic criteria for high suicide risk among men and women with different types of dementia basing on the distinguished gender peculiarities. To determine the differences in the formation of depressive symptoms in both groups we used Hamilton Depression Rating Scale (HDRS) (Hamilton M.,
1967), the method of statistical processing of the results using the degree of Kulbak's informative and diagnostic coefficients.

Conflict of interests. There is no conflict of interests.

3. Results and discussion. We conducted the detailed analysis of the components of depressive symptoms, as shown in the following tables.

The total score of depression according to Hamilton scale in the comparable groups was high and comprised (32.2 \pm 1.22 points) among men and (31 \pm 2.71$)$ among women. As it can be seen from the Table 1 in men with dementia in Alzheimer's disease in the structure of depression 
prevailed such symptoms as depressive mood (1.71 \pm 0.27 points), suicidal intentions (3.04 \pm 0.34 points), inability to perform work and to activity (3.61 \pm 0.17 points), inhibition (2.57 \pm 0.22 points), excitement (2.23 \pm 0.32 points), mental anxiety ( $2.04 \pm 0.31$ points) , decrease of criticism (1.19 \pm 0.16 points). At the same time, men in comparison with women had a decrease in critical thinking $(\mathrm{p}<0.05$; $\mathrm{DC}=0.737$; $\mathrm{MI}=$ 0.351 ); the presence and severity of suicidal intentions ( $<<0.01$; $\mathrm{DC}=0.607$; $\mathrm{MI}=0.636)$; inhibition of the pace of mental activity $(\mathrm{p}<0.05$;
$\mathrm{DC}=0.525 ; \mathrm{MI}=0.412)$ as diagnostic significance in determining the risk of suicide.

Clinico-psychopathological states of depression in women with Alzheimer's disease included depressive mood (1.79 \pm 0.35 points), decreased activity and productivity at work (3.78 \pm 0.11 points), psychomotor agitation (2.35 \pm 0.42 points), manifestations of somatic anxiety (flatulence, diarrhea, dry mouth, palpitation, headaches, increased sweating) (1.78 \pm 0.35 points), gastrointestinal and general-somatic symptoms (loss of appetite, constipation, severity

Gender characteristics of depressive symptoms in patients with vascular disorders (according to Hamilton scale)

\begin{tabular}{|c|c|c|c|c|c|c|}
\hline Indicator & Men & Women & $\begin{array}{c}\mathrm{t}- \\
\text { value }\end{array}$ & $\mathrm{P}$ & $\begin{array}{c}\text { DC } \\
\text { (diag- } \\
\text { nostic } \\
\text { coeffi- } \\
\text { cient) } \\
\end{array}$ & $\begin{array}{c}\text { MI } \\
\text { (measure } \\
\text { of infor- } \\
\text { mative- } \\
\text { ness) }\end{array}$ \\
\hline & \multicolumn{6}{|c|}{$\mathrm{M} \pm \mathrm{SD}$} \\
\hline 1 & 2 & 3 & 4 & 5 & 6 & 7 \\
\hline Depressive mood & $2 \pm 0.21$ & $1.85 \pm 0.32$ & 0.362 & - & 0.107 & 0.015 \\
\hline Feeling of guilt & $1.6 \pm 0.23$ & $1.21 \pm 0.21$ & 1.204 & - & 0.397 & 0.153 \\
\hline Suicidal intentions & $2.28 \pm 0.3$ & $0.42 \pm 0.13$ & 5.190 & $p<0.001$ & 2.411 & 4.464 \\
\hline Early insomnia & $1.24 \pm 0.15$ & $1.64 \pm 0.13$ & 1.967 & - & -0.405 & 0.163 \\
\hline Middle insomnia & $1.36 \pm 0.16$ & $1.35 \pm 0.22$ & 0.010 & - & 0.003 & 8.686 \\
\hline Late insomnia & $0.84 \pm 0.18$ & $1.21 \pm 0.11$ & 1.698 & - & -0.531 & 0.198 \\
\hline Work and activity & $3.64 \pm 0.09$ & $2.71 \pm 0.41$ & 2.187 & $\mathrm{p}<0.05$ & 0.423 & 0.391 \\
\hline Inhibition & $2.2 \pm 0.16$ & $1.42 \pm 0.29$ & 2.310 & $\mathrm{p}<0.05$ & 0.623 & 0.480 \\
\hline Excitement & $2.4 \pm 0.24$ & $1.14 \pm 0.20$ & 3.928 & $\mathrm{p}<0.001$ & 1.070 & 1.345 \\
\hline Mental anxiety & $1.92 \pm 0.25$ & $1.07 \pm 0.30$ & 2.125 & $\mathrm{p}<0.05$ & 0.841 & 0.714 \\
\hline Somatic anxiety & $2.24 \pm 0.21$ & $1.42 \pm 0.13$ & 3.230 & $\mathrm{p}<0.01$ & 0.648 & 0.526 \\
\hline $\begin{array}{l}\text { May somatic viola- } \\
\text { tions }\end{array}$ & $0.72 \pm 0.12$ & $0.42 \pm 0.13$ & 1.582 & - & 0.748 & 0.218 \\
\hline $\begin{array}{l}\text { General somatic } \\
\text { symptoms }\end{array}$ & $1.76 \pm 0.08$ & $1.35 \pm 0.22$ & 1.669 & - & 0.375 & 0.151 \\
\hline Genital symptoms & $1.36 \pm 0.19$ & $0.42 \pm 0.22$ & 3.138 & $\mathrm{p}<0.01$ & 1.665 & 1.551 \\
\hline Hypochondria & $1.8 \pm 0.28$ & $0.85 \pm 0.32$ & 2.172 & $\mathrm{p}<0.05$ & 1.070 & 1.00 \\
\hline Weight loss & $0.48 \pm 0.14$ & $0.71 \pm 0.19$ & 0.972 & - & -0.567 & 0.131 \\
\hline Weight loss (actual) & $0.36 \pm 0.14$ & $0.42 \pm 0.13$ & 0.349 & - & -0.251 & 0.017 \\
\hline Criticism & $1.04 \pm 0.20$ & $0 \pm 0$ & 5.099 & $\mathrm{p}<0.001$ & 0 & 0 \\
\hline Daily fluctuations & $0.84 \pm 0.16$ & $0.57 \pm 0.13$ & 1.274 & - & 0.555 & 0.149 \\
\hline $\begin{array}{l}\text { Daily fluctuations } \\
\text { (degree) }\end{array}$ & $0.84 \pm 0.18$ & $1 \pm 0.18$ & 0.611 & - & -0.251 & 0.040 \\
\hline $\begin{array}{l}\text { Depersonalization/de } \\
\text { realisation }\end{array}$ & $0.56 \pm 0.20$ & $1.07 \pm 0.35$ & 1.254 & - & -0.936 & 0.478 \\
\hline Paranoid symptoms & $2 \pm 0.29$ & $0 \pm 0$ & 6.793 & $\mathrm{p}<0.001$ & 0 & 0 \\
\hline $\begin{array}{l}\text { Obsessive and } \\
\text { compulsive } \\
\text { symptoms }\end{array}$ & $0.32 \pm 0.13$ & $0 \pm 0$ & 2.317 & $\mathrm{p}<0.05$ & 0 & 0 \\
\hline Total score & $33.8 \pm 2.30$ & $22.35 \pm 1.88$ & 3.846 & $\mathrm{p}<0.001$ & 7.998 & 12.201 \\
\hline
\end{tabular}


Gender peculiarities of depressive symptoms in patients with mixed disorders

Table 3 (according to Hamilton scale)

\begin{tabular}{|l|c|c|c|c|c|c|c|}
\hline \multicolumn{1}{|c|}{ Indicator } & $\begin{array}{c}\text { Men } \\
(\mathrm{n}=15)\end{array}$ & $\begin{array}{c}\text { Women } \\
(\mathrm{n}=15)\end{array}$ & $\mathrm{t}$-value & $\mathrm{P}$ & $\begin{array}{c}\text { DC } \\
\text { (diagnostic } \\
\text { coefficient) }\end{array}$ & $\begin{array}{c}\text { MI (measure } \\
\text { of infor- } \\
\text { mativeness })\end{array}$ \\
\cline { 2 - 8 } & \multicolumn{5}{|c|}{$\mathrm{M} \pm \mathrm{SD}$} \\
\hline & 2 & 3 & 4 & 5 & 6 & 7 \\
\hline Depressive mood & $1.4 \pm 0.21$ & $2.73 \pm 0.22$ & 4.26 & $\mathrm{p}<0.001$ & -0.963 & 1.281 \\
\hline Feeling of guilt & $2.33 \pm 0.34$ & $2.73 \pm 0.22$ & 0.96 & - & -0.228 & 0.091 \\
\hline Suicidal intentions & $1.33 \pm 0.41$ & $2.73 \pm 0.22$ & 2.98 & $\mathrm{p}<0.01$ & -1.037 & 1.452 \\
\hline Early insomnia & $0.53 \pm 0.21$ & $0.93 \pm 0.22$ & 1.275 & - & -0.811 & 0.324 \\
\hline Middle insomnia & $0.47 \pm 0.13$ & $1.33 \pm 0.18$ & 3.77 & $\mathrm{p}<0.001$ & -1.500 & 1.290 \\
\hline Late insomnia & $0.53 \pm 0.19$ & $0.8 \pm 0.24$ & 0.861 & - & -0.594 & 0.160 \\
\hline Work and activity & $3.2 \pm 0.29$ & $3.2 \pm 0.22$ & 0 & - & - & - \\
\hline Inhibition & $2.13 \pm 0.37$ & $2.53 \pm 0.32$ & 0.807 & - & -0.24 & 0.097 \\
\hline Excitement & $1.13 \pm 0.32$ & $1.47 \pm 0.37$ & 0.673 & - & -0.379 & 0.129 \\
\hline Mental anxiety & $0.8 \pm 0.17$ & $1.87 \pm 0.38$ & 2.503 & $\mathrm{p}<0.05$ & -1.22 & 1.310 \\
\hline Somatic anxiety & $2.07 \pm 0.34$ & $1.87 \pm 0.25$ & 0.466 & - & 0.146 & 0.029 \\
\hline $\begin{array}{l}\text { May somatic viola- } \\
\text { tions }\end{array}$ & $1.07 \pm 0.26$ & $0.67 \pm 0.12$ & 1.35 & - & 0.675 & 0.270 \\
\hline $\begin{array}{l}\text { General somatic } \\
\text { symptoms }\end{array}$ & $1.47 \pm 0.21$ & $1.27 \pm 0.11$ & 0.814 & - & 0.210 & 0.042 \\
\hline Genital symptoms & $1.47 \pm 0.21$ & $0 \pm 0$ & 6.812 & $\mathrm{p}<0.001$ & - & - \\
\hline Hypochondria & $1.87 \pm 0.33$ & $1.33 \pm 0.31$ & 1.151 & - & 0.491 & 0.265 \\
\hline Weight loss & $1.07 \pm 0.20$ & $0.27 \pm 0.11$ & 3.365 & $\mathrm{p}<0.01$ & 1.986 & 1.589 \\
\hline Weight loss (actual) & $0 \pm 0$ & $0.13 \pm 0.09$ & 1.467 & - & - & - \\
\hline Criticism & $0.87 \pm 0.19$ & $1.07 \pm 0.24$ & 0.637 & - & -0.298 & 0.059 \\
\hline Daily fluctuations & $0.87 \pm 0.23$ & $0.8 \pm 0.24$ & 0.196 & - & 0.121 & 0.008 \\
\hline $\begin{array}{l}\text { Daily fluctuations } \\
\text { (degree) }\end{array}$ & $1.07 \pm 0.26$ & $0.93 \pm 0.22$ & 0.379 & - & 0.202 & 0.028 \\
\hline $\begin{array}{l}\text { Depersonalization/dere } \\
\text { alisation }\end{array}$ & $0.8 \pm 0.24$ & $0.26 \pm 0.18$ & 1.75 & - & 1.583 & 0.843 \\
\hline Paranoid symptoms & $1.27 \pm 0.38$ & $1.47 \pm 0.40$ & 0.360 & - & -0.210 & 0.042 \\
\hline $\begin{array}{l}\text { Obsessive and } \\
\text { compulsive symptoms }\end{array}$ & $0.34 \pm 0.12$ & $0.13 \pm 0.09$ & 1.287 & - & 1.387 & 0.291 \\
\hline Total score & $28.06 \pm 2.1$ & $30.53 \pm 2.14$ & 0.817 & - & -0.691 & 9.608 \\
\hline
\end{tabular}

in limbs, muscle aches, lack of vital forces) (1.28 \pm 0.22 and $1.5 \pm 0,13$ points, respectively). Women were more likely to lose weight ( $1 \pm 0.27$ points), had diurnal mood fluctuations ( $1.57 \pm 0.22$ points) in a marked degree (1.28 \pm 0.22 points), and had delusions ( $1.28 \pm 0.22$ points).

The significant differences were found between two groups, which consisted in the prevalence of daily mood fluctuation in women ( $\mathrm{p}<0.001 ; \mathrm{DC}=-3.044 ; \mathrm{MI}=4.204)$ and their severity $(\mathrm{p}<0.00 ; \mathrm{DC}=-2.754$; $\mathrm{MI}=3.017)$; paranoid symptoms ( $<0.01 ; \mathrm{DK}=-1.910 ; \mathrm{MI}=3.013)$ compared with men.

Assessment of clinical and psychopathological structure of depressive syndrome as a part of vascular dementia among men showed a severe degree of depression (33.8 \pm 2.30 points), and moderate in women $(22.35 \pm 1.88)$, while the accuracy of the differences corresponded to the level $(p<0.001)$. Men with a high risk of suicide in the vascular form of the dementia were more vulnerable than women as to the development of comorbid depressive symptoms (DC = 7.998; $\mathrm{MI}=$ 12.201), with marked depressive mood $(2 \pm 0.21$ points), suicidal intentions ( $2.28 \pm 0.3$ points) showed the inability to perform activities and work (3.64 \pm 0.09 points), torpidity of thinking ( $2.2 \pm$ $0.16)$, mental and somatic anxiety (1.92 \pm 0.25 and $2.24 \pm 0.21$ ), psychomotor agitation (2.4 \pm 0.24 points), delusions ( $2 \pm 0.29$ points), sexual 
function disorders (1.36 \pm 0.19 points) and decreased critical thinking abilities (1.04 \pm 0.20 points).

Thus, assessment of depressive symptoms in patients with vascular dementia allowed to determine that the high levels of depression (DC $=7.998 ; \mathrm{MI}=12.201$ ), suicidal intentions $(\mathrm{p}<0.001 ; \mathrm{DC}=2.411 ; \mathrm{MI}=4.464)$; inability to perform work $(\mathrm{p}<0.05$; $\mathrm{DC}=0.423$; $\mathrm{MI}=$ 0.391); inhibition of thinking ( $<<0.05$; $\mathrm{DC}=0.623$; $\mathrm{MI}=0.480)$; mental $(\mathrm{p}<0.05 ; \mathrm{DC}=0.841 ; \mathrm{MI}=$ $0.714)$ and somatic anxiety $(\mathrm{p}<0.01 ; \mathrm{DC}=0.648$; $\mathrm{MI}=0.526)$; predisposition to hypochondria $(\mathrm{p}<0.05 ; \mathrm{DC}=1.070 ; \mathrm{MI}=1.00)$; genital symptoms $(\mathrm{p}<0.01 ; \mathrm{DC}=1.665 ; \mathrm{MI}=1.551)$ prevailed aamong men with high SR.

Moderate severity of depression and its components are the marker of high suicide risk for women with vascular dementia $(\mathrm{p}<0.001$; $\mathrm{DC}=7.998$; $\mathrm{MI}=12.201$ ).

Gender characteristics of depressive symptoms in patients with mixed dementia (due to aggregation of the vascular and neurodegenerative process) consisted in prevalence of deep depression among examined women ( $2.73 \pm 0.22$ points $)$ with a feeling of guilt and suicidal intentions $(2.73 \pm 0.22$ points, respectively), frequent wakening at night (1.33 \pm 0.18 points), decrease of real time of daily activity (3.2 \pm 0.22 points), ideational retardation ( $2.53 \pm$ 0.32 points), moderately expressed mental and somatic anxiety (1.87 \pm 0.38 points).

The peculiarities of depressive syndrome in a mixed type of dementia in men consisted in a moderate mood decrease ( $1.4 \pm 0.21$ points), mental anxiety ( $0.8 \pm 0.17$ points), suicidal manifestations in the form of antivital mood (1.33 \pm 0.41 points) and expressed feelings of guilt (2.33 \pm 0.34 points), retardation ( $2.13 \pm 0.37$ points), somatic anxiety (2.07 \pm 0.44$)$, predisposition to hypochondria (1.87 \pm 0.33 points).

On the basis of statistical analysis, the significant differences between two comparable groups were established, which consisted in the prevalence of depressive mood in women $(\mathrm{p}<0.001 ; \mathrm{DC}=-0.963 ; \mathrm{MI}=1.281)$ secondary to severe anxiety $(\mathrm{p}<0.05$; $\mathrm{DC}=-1.22$; $\mathrm{MI}=$ 1.31); suicidal intentions ( $<<0.01 ; \mathrm{DC}=-1.037$; $\mathrm{MI}=1.452)$; with frequent wakening at night $(\mathrm{p}<0.001 ; \mathrm{DC}=-1.500 ; \mathrm{MI}=1.290)$.

Instead, in men secondary to subdepressive $\operatorname{mood}(\mathrm{p}<0.001 ; \mathrm{DC}=-0.963 ; \mathrm{MI}=1.281)$ and suicidal manifestations in the form of antivital expressions $(\mathrm{p}<0.01 ; \mathrm{DC}=-1.037 ; \mathrm{MI}=1.452)$ disturbance of sexual function $(\mathrm{p}<0.001)$ and weight loss $(\mathrm{p}<0.01 ; \mathrm{DC}=1.986 ; \mathrm{MI}=1.589)$ were of high severity.

Conclusions. Thus, the following features of depressive symptoms refer to the gender diagnostic informative criteria of high risk of suicide:

In dementia due to Alzheimer's disease:

- in men: expressed suicidal manifestations $(\mathrm{DC}=0.607 ; \mathrm{MI}=0.636)$ and torpidity of mental processes $(\mathrm{DC}=0.525 ; \mathrm{MI}=0.412)$ secondary to lack of critical thinking relating to his condition $(\mathrm{DC}=0.737$; $\mathrm{MI}=0.351$;

-in women: daily mood fluctuations ( $\mathrm{p}<0.001$; $\mathrm{DC}=-3.044 ; \mathrm{MI}=4.204$ ) and their severity (DC $=-2.754 ; \mathrm{MI}=3.017$ ); paranoid symptoms $(\mathrm{DC}=-1.910 ; \mathrm{MI}=3.013)$.

\section{In vascular dementia:}

-in men: high level of depression ( $\mathrm{DC}=7.998$; $M I=12.201)$; suicidal intentions $(D C=2.411$; $\mathrm{MI}=4.464)$; inability to perform work $(\mathrm{DC}=$ $0.423 ; \mathrm{MI}=0.391)$; torpidity of thinking $(\mathrm{DC}=$ $0.623 ; \mathrm{MI}=0.480) ;$ mental $(\mathrm{DC}=0.841 ; \mathrm{MI}=$ $0.714)$ and somatic anxiety $(\mathrm{DC}=0.648 ; \mathrm{MI}=$ 0.526 ); predisposition to hypochondria ( $\mathrm{DC}=$ 1.070; $\mathrm{MI}=1.00)$; genital symptoms $(\mathrm{DC}=1.665$; $\mathrm{MI}=1.551$;

- in women: mild and moderate severity of depressive syndrome and its components $(\mathrm{DC}=7.998 ; \mathrm{MI}=12.201)$.

\section{In mixed dementia:}

- in men: mild depression ( $\mathrm{DC}=-0.963$; $\mathrm{MI}=1.281)$ and weight loss $(\mathrm{DC}=1.986$; $\mathrm{MI}=1.589$;

- in women: severe depression (DC $=-0.963$; $\mathrm{MI}=1.281)$; anxiety $(\mathrm{DC}=-1.22 ; \mathrm{MI}=1.31)$; suicidal intentions $(\mathrm{DC}=-1.037 ; \mathrm{MI}=1.452)$; frequent wakening at night $(\mathrm{p}<0.001 ; \mathrm{DC}=$ -1.500; MI = 1.290).

\section{References:}

1. Jacina A.T. (2014) Genderno zumovlen ${ }^{3}$ patopsiholog ${ }^{3} \mathrm{chn}^{3}$ zakonom$^{3} \mathrm{rnost}^{3}$ formuvannja depresivnih $\operatorname{rozlad}^{3} \mathrm{~V}$ u cholov ${ }^{3} \mathrm{k}^{3} \mathrm{v}$ [Gender-determined pathopsychological patterns of the formation of depressive disorders in men]. Medichna psiholog3ja, no 3, pp. 84-89.

2. Maruta N.O., Snovida L.T. (2012) Genderno zumovlena specif3ka su¿cidal'no¿ poved³nki u hvorih na depres ${ }^{3} \dot{c}$ [Gender is determined by the specifics of suicidal behavior in patients with depression]. Medicina s'ogodn ${ }^{3}$ zavtra, no 3-4 (56-57), pp.126-132. 
3. Mudrenko ${ }^{2}$.G. (2017) $\mathrm{Kl}^{3} n^{3}{ }^{k}$ o-psihopatolog${ }^{3} \mathrm{chna}$ struktura depresivnih rozlad ${ }^{3} \mathrm{v}$ u hvorih na demenc ${ }^{3} \mathrm{c}$ $\mathrm{z}$ visokim rizikom sujcidu [Clinico-psychopathological structure of depressive disorders in patients with dementia with high suicide risk]. Arh $^{3} \mathrm{v}_{\text {psih }}{ }^{3} \mathrm{atr}^{3} \dot{\mathrm{c}}$. Vol. 23, no 4(91), pp. 38-43.

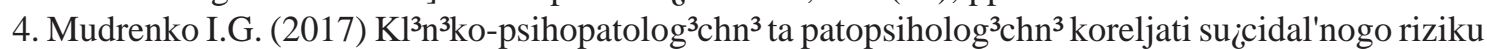
$\mathrm{u}$ hvorih na demenc ${ }^{3} \dot{c}$ [Clinico-psychopathological and pathopsychological correlates of suicidal risk in patients with dementia]. Journal of Clinical and Experimental Research, vol. 5, no. 4, pp.46-51.

5. Mudrenko ${ }^{2}$.G. (2017) Farmakolog ${ }^{3} \mathrm{chna}$ korekc ${ }^{3} \mathrm{ja}$ depresivnih simptom ${ }^{3} \mathrm{v}$ u hvorih $\mathrm{z} \mathrm{r}^{3} \mathrm{znimi}$ $\mathrm{kl}^{3} \mathrm{n}^{3} \mathrm{chnimi}$ var ${ }^{3}$ antami demenc $\mathrm{c}^{3}$ [Pharmacological correction of depressive symptoms in patients with different clinical variants of dementia]. Ukraęns'kij v³nik psihonevrologi3 ¿ vol. 25, no 3(92), pp.49-53.

Received: 30-Jun. - 2018

Accepted: 09-Dec. - 2018 